\title{
Effects of Deer Grazing on Vegetation and Ground-Dwelling Insects in a Larch Forest in Okutama, Western Tokyo
}

\author{
Hodaka Yamada and Seiki Takatsuki \\ School of Veterinary Medicine, Azabu University, 1-17-71 Fuchinobe, Chuo-ku, Sagamihara, Kanagawa 229-859, Japan \\ Correspondence should be addressed to Seiki Takatsuki; takatuki@azabu-u.ac.jp
}

Received 30 July 2014; Revised 3 December 2014; Accepted 22 December 2014

Academic Editor: Alejandro Solla

Copyright ( $) 2015$ H. Yamada and S. Takatsuki. This is an open access article distributed under the Creative Commons Attribution License, which permits unrestricted use, distribution, and reproduction in any medium, provided the original work is properly cited.

Sika deer (Cervus nippon) have experienced a rapid increase in the Japanese archipelago. Although the effects of deer grazing have been widely studied, the indirect effects have received little attention. Using an eight-year-old deer exclosure in western Tokyo (Japan), we studied the direct effects on plants and the indirect effects on insects and microenvironments. Plant biomass was 14 times higher inside the exclosure than outside. Shrubs (e.g., Aralia elata and Hydrangea paniculata) and trees (e.g., Symplocos sawafutagi and Clethra barbinervis) were more abundant inside, whereas only unpalatable trees in poor condition grew outside (e.g., Pterostyrax hispida and Cynanchum caudatum). In the summer months, the maximum temperature was $8-10^{\circ} \mathrm{C}$ higher outside the exclosure and humidity was lower. Soil movement was 80 times more pronounced outside than inside. These results suggest that the abiotic environment became less stable for ground-dwelling insects. Carabid beetles were less abundant outside than inside, suggesting that deer grazing reduced plants and subsequently lowered habitat quality for these beetles. In contrast, carrion beetles, dung beetles, and camel crickets were more abundant outside. The increase in these insects is attributed to the availability of deer feces and carcasses and is a direct effect of deer presence.

\section{Introduction}

Grazing by deer (Cervidae) affects vegetation in various ways, for example, by reducing undergrowth in forests [1-3], increasing the number of unpalatable plants $[4,5]$, blocking forest regeneration [3-8], and affecting seed dispersal [9]. Populations of sika deer (Cervus nippon) have increased in Japan: from 1978 to 2003 and their range expanded 74\% $[10,11]$. As a result, vegetation has been affected $[1,7,12]$.

The effects of deer grazing on vegetation have been widely studied $[1,2,4,6,7,13-15]$, but the indirect effects have received little attention. One typical indirect effect is a decrease in herbivorous insects due to a reduction in plant leaves caused by deer grazing. McShea [16] found that consumption of acorns by white-tailed deer decreased the populations of some rodents in the eastern USA. Miller et al. [14] reported a phenomenon of white-tailed deer (Odocoileus virginianus) reducing populations of a forb, Lupinus perennis, which led to a decrease in the population of endangered butterfly Lycaeides melissa samuelis in New England, USA.
Wheatall et al. [17] demonstrated a marked decrease in phytophagous insect larvae caused by white-tailed deer grazing in the eastern USA, and Baines et al. [18] showed that grazing by red deer (Cervus elaphus) reduced Lepidopterous larvae in Scotland. These indirect effects occur through food webs or as a result of food resource changes.

Structural changes in plant communities caused by ungulate grazing can lead to abiotic environment alteration and have indirect effects on other animals. Studies have shown the decline in the number of small mammals through habitat alteration by deer grazing, for example, Rocky Mountain elk (Cervus elaphus) in Arizona, USA [19], and several cervids in Britain [20]. Population reduction due to habitat alteration by deer grazing is also known to affect birds [21-23]. Similar effects have been observed on insects. Long-term grazing by the Sitka black-tailed deer (Odocoileus hemionus sitkensis) lowered the numbers and species richness of insects of various taxa on islands in British Columbia, Canada [24]. Studies in boreal forests showed that ungulate grazing can affect carabid beetle populations, but the results are not 
consistent. Some studies reported an increase in carabid beetles as a result of ungulate grazing [25-28], whereas others reported no effect $[29,30]$. In Japan, sika deer grazing decreased Sasa nipponica, a dwarf bamboo, but did not affect carabid beetle populations [31].

Plant reduction caused by sika deer grazing also leads to the loss of surface soil [32-35]. In and around the area of the present study, the leaves of Sasamorpha borealis, a dwarf bamboo that covers the forest floor, were heavily grazed by the deer and plants were dying. As the rhizomes of this bamboo are soil binding, mortality of this plant is likely to accelerate soil erosion.

We investigated the direct effects of sika deer grazing on plant populations and the indirect effects on insects and abiotic environments in western Tokyo, Japan, using an eightyear-old deer exclosure. We hypothesized that deer grazing would reduce plants and this direct effect would have indirect effects on the microclimate and soil movements. These changes would then indirectly affect ground-dwelling insects. At the same time, it is expected that the availability of deer feces and carcasses would favor decomposer insects such as dung beetles and carrion beetles (direct rather than indirect effects). We tested these hypotheses by making comparisons inside and outside the exclosure.

\section{Study Area}

We selected a study area in Okutama, western Tokyo. The topography of Okutama is generally steep: above $500 \mathrm{~m}$, the gradient is $30^{\circ}$ or more. Beech (Fagus crenata) forest is predominant in the area at $1000-1700 \mathrm{~m}$. Japanese hemlock (Tsuga sieboldii) and Nikko fir (Abies homolepis) are predominant in the subalpine forest above $1700 \mathrm{~m}$. The study area is in the climate zone of the Pacific side of Japan, where precipitation is concentrated in summer and the climate is dryer in winter [36]. Annual mean temperature and precipitation are $11.8^{\circ} \mathrm{C}$ and $1586 \mathrm{~mm}$, respectively (Meteorological Information Center of Japan, http://www.data.jma.go.jp/obd/stats/etrn/index.php).

Sika deer were virtually extinct in this area in the 1940s and hunting was prohibited in 1976. After this, the deer population gradually recovered and agricultural and forestry damage began in the 2000s [10]. Although deer density is only $3.8 / \mathrm{km}^{2}$ [10], $60 \%$ of the area is covered by a coniferous plantation [37] with a poor forest floor, resulting in very intensive deer grazing and browsing [1]. Using a deer exclosure built in 2003, we were able to compare plants, insects, and microenvironments inside and outside the construction.

\section{Methods}

Densities of fecal pellet groups were determined on 20 plots $(5 \mathrm{~m} \times 5 \mathrm{~m})$ as an index for deer density.

The deer exclosure was built in 2003 in a larch (Larix kaempferi) forest on a gentle slope at $1360 \mathrm{~m}$ (Figure 1). It covers about 1 ha and is built of plastic wire mesh hung from $2 \mathrm{~m}$ high poles. Surveys were conducted in 2011, eight years after construction.

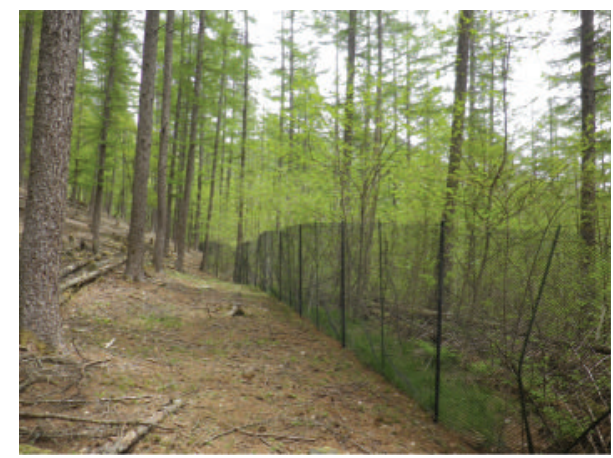

FIgURE 1: View of the eight-year-old deer exclosure in a larch forest in Okutama, western Tokyo, Japan. Photo taken in May, 2011.

Tree composition was determined by obtaining the diameter at breast height $(\mathrm{DBH})$ of trees taller than $1.2 \mathrm{~m}$ on a $10 \mathrm{~m} \times 10 \mathrm{~m}$ plot inside the exclosure and a $20 \mathrm{~m} \times 20 \mathrm{~m}$ plot outside. The inside plot was set in the center of the exclosure and the outside plot was established about $20 \mathrm{~m}$ away from it on the same slope. Recordings were taken on July 4, 2011.

The cover $(\%)$ and the height $(\mathrm{cm})$ to the nearest $1 \mathrm{~cm}$ of all plants present on five $2 \mathrm{~m} \times 2 \mathrm{~m}$ quadrants both inside and outside the exclosure were recorded on June 25, 2011. Plots approximately $10 \mathrm{~m}$ apart were randomly defined inside and outside the exclosure. The biomass index for each plant species was calculated by multiplying height $(\mathrm{cm})$ by cover $\left(\mathrm{cm}^{2} / \mathrm{m}^{2}\right)$ [38]. A total biomass index of each growth form was determined, following a partly modified version of Gimingham [39]: e: erect form; fe: fern form; g: graminoids (tufted form); l: liane form; r: rosette form; sh: shrub form; and t: tree form. Palatability for sika deer was also recorded. The number of plant species and the biomass indices inside and outside the exclosure were compared using a Mann-Whitney $U$ test. Diversity of species composition was expressed by the Shannon-Wiener diversity index $\left(H^{\prime}=\right.$ $-\sum p_{i} \times \log _{2} p_{i}$, where $p_{i}$ is the proportion of individuals belonging to species $i$ ).

Microclimate (temperature and humidity) on the ground was measured using data loggers (TR-74Ui, T and D Corp., Japan) from June 25 to October 19, 2011. The sensor was inserted into a polyvinyl chloride pipe $(200 \mathrm{~mm}$ long; $80 \mathrm{~mm}$ diameter) and the pipe was laid on the ground. The mean, maximum and minimum temperature, and humidity values were calculated. Microclimate values inside and outside the exclosure were compared using the Mann-Whitney $U$ test.

Four wooden boxes $(150 \mathrm{~mm}$ high $\times 250 \mathrm{~mm}$ wide $\times$ $200 \mathrm{~mm}$ deep) were used to determine soil movements at the ground surface. Two boxes were placed inside and two outside the exclosure. The rear of each box was covered with mesh net to allow water to pass through. On June 25, 2011, the boxes were placed on the surface of the ground in a location with a $32^{\circ}$ gradient. We collected soil from the boxes from July 4 to October 2, 2011, approximately every 10 days, except for some stormy days when typhoons hit. After collection, the soil was dried at $60^{\circ} \mathrm{C}$ for $48 \mathrm{~h}$ in an oven dryer and dry weights were recorded. The weights inside and outside the exclosure were compared using a Mann-Whitney $U$ test. 
Insects were collected in pitfall traps [40]. Twenty plastic cups ( $67 \mathrm{~mm}$ diameter at top) were buried in the ground so that the top edge of the cup was at the same level as the surface of the soil. Cups were placed about $1 \mathrm{~m}$ apart. Outside the exclosure, the cups were placed about $20 \mathrm{~m}$ away from the construction. Surfactant liquid was put in the bottom of the cups to stop insects from escaping. The traps were set for 88 trap nights from June 9 to October 2 , 2011. The sampling interval was ca. 10 days except for some stormy days. Insects found in the traps were brought to the laboratory, identified, and counted. Although grouping was not consistent in terms of taxonomical hierarchy, groups containing numerous individuals were divided to the lower level and less numerous groups were "rounded." Beetles were sorted into carrion beetles, carabid (or ground) beetles (Carabidae and Harpalinae), dung beetles, rove beetles or staphylinids (Staphylinidae), and others. Other insects were grouped to the order level. After checking for normality, differences between the major insect groups inside and outside the exclosure were tested by either Student's $t$-test or the Mann-Whitney $U$ test. Diversity was determined by the Shannon-Wiener index of diversity $\left(H^{\prime}\right)$.

\section{Results}

The mean value of the density of fecal pellet groups of the sika deer in the study area was $3.90 \pm 1.96$ group $/ 10 \mathrm{~m}^{2}$.

The total basal area of trees inside and outside the exclosure $\left(1743 \mathrm{~cm}^{2} / \mathrm{m}^{2}\right.$ and $1909 \mathrm{~cm}^{2} / \mathrm{m}^{2}$, resp.) showed no significant differences (Mann-Whitney $U$ test, $P>0.05$, Table 1). This is because of the dominance of larch (Larix kaempferi) trees on both sides of the exclosure. However, the results for smaller trees were different: 12 tree species were present inside the exclosure but only four occurred outside (Table 1), and five shrub species with a density as high as $89.0 / 100 \mathrm{~m}^{2}$ grew inside but no shrubs grew outside.

The plant species documented in the understory on the five plots inside and outside the exclosure totaled 41 and 26 , respectively. The mean number of plant species found inside (14.4 species) was significantly higher than outside (9.7 species, Mann-Whitney $U$ test, $P<0.01$, Table 2). Biomass indices were higher inside (14.4 times, Mann-Whitney $U$ test, $P<0.01)$, and diversity indices $\left(H^{\prime}\right)$ were also significantly higher inside $\left(H^{\prime}=2.86\right)$ than outside $\left(H^{\prime}=1.77\right.$, Table 2$)$.

The dominant plants (plant form type) inside the exclosure were Aralia elata (sh: shrub form), Hydrangea paniculata (sh), Callicarpa japonica (sh), Symplocos sawafutagi (t: tree form), and Clethra barbinervis ( $\mathrm{t}$, Table 3 ). These woody plants accounted for more than $80 \%$ of the biomass index inside. Outside the exclosure, Cynanchum caudatum (l: liane form, u: unpalatable), Pterostyrax hispida ( $\mathrm{t}, \mathrm{u}$ ), and Festuca rubra (g: graminoid) accounted for more than $90 \%$ of the total biomass index outside (Table 3). These results show that heavy deer grazing not only reduced biomass, but also decreased species and growth form diversities. Species-area curves clearly showed no difference in species numbers between the inside and the outside at smaller plot size, but, as plot size increased, differences appeared and became more pronounced (Figure 2).

The temperature was recorded inside and outside the exclosure from late June to October. From June to August, the maximum temperature was often higher outside than inside but was similar on both sides in September and October (Figure 3(a)). The minimum temperatures on each side were similar from late June to September (Figure 3(b)). In October, however, the minimum temperature was lower outside than inside.

The highest humidity values in July were almost 100\% both inside and outside, but in late July and early August they decreased and were slightly lower outside. From midSeptember, humidity values increased again to almost $100 \%$ inside but were around 40-60\% outside (Figure 4(a)). The lowest humidity values were more variable than the maximum values. Outside values were lower in late July and August and early September and October (Figure 4(b)).

Daily fluctuations in temperature and humidity from July 5 to July 12, 2011, are shown in Figure 5 as an example. The nocturnal temperature showed no difference between the inside and outside, but diurnal values followed a different pattern. During the day, the highest temperature outside showed sharp "peaks" on sunny days that were not observed inside (Figure 5(a)). Similarly, the humidity outside showed sharp "valleys," dropping to about $50 \%$ on sunny days, whereas the values inside rarely fell below $80 \%$ (Figure 5(b)).

The diurnal temperature and humidity ranges were higher outside than inside (Figure 6). The monthly means were significantly higher outside in July, August, and October (Mann-Whitney $U$ test, $P<0.05$ ) but not in September $(P>0.05)$. These results suggest that the microclimate was less stable outside than inside because of plant reduction.

The mean amount of soil captured in the boxes outside the exclosure (8.04 g/day) was 80 times higher than the amount in the boxes inside $(0.11 \mathrm{~g} /$ day, Mann-Whitney $U$ test, $P<0.01)$. The amount of soil captured outside increased in June and then dropped before increasing again in the middle of August and September (Figure 7), when typhoons hit the area.

During the study period, the insects collected inside and outside the exclosure totaled 950 and 1,682, respectively. Table 4 shows the insect groups that included more than 100 individuals. The number of carabid beetles collected inside $(10.9 / 100 \mathrm{TN})$ was significantly higher than outside (3.8/100 TN, Mann-Whitney $U$ test, $P<0.01)$. In contrast, carrion beetles (Silphidae, 5.8/100 TN inside, 8.5/100 TN outside), dung beetles (8.0/100 TN inside, 35.5/100 TN outside), and camel crickets (6.3/100 TN inside, $12.4 / 100 \mathrm{TN}$ outside) were significantly more abundant outside (Mann-Whitney $U$ test, $P<0.01$ ). Densities of ground beetles and rove beetles, or staphylinids (Staphylinidae), were not significantly different between the two sides (Mann-Whitney $U$ test, $P>$ 0.05). Diversity indices were 3.02 inside and 2.79 outside.

\section{Discussion}

As the exclosure was located in a single larch forest, the canopy trees were the same inside and outside. 
TABLE 1: Densities and basal area of trees and shrubs appearing in $10 \mathrm{~m} \times 10 \mathrm{~m}$ plot inside and $20 \mathrm{~m} \times 20 \mathrm{~m}$ plot outside the exclosure at Okutama, western Tokyo, Japan.

\begin{tabular}{|c|c|c|c|c|c|}
\hline & \multirow{2}{*}{ Tree/shrub } & \multicolumn{2}{|c|}{ Inside } & \multicolumn{2}{|c|}{ Outside } \\
\hline & & $n /$ plot & Basal area $\left(\mathrm{m}^{2} / \mathrm{ha}\right)$ & $n / 100 \mathrm{~m}^{2}$ & Basal area $\left(\mathrm{m}^{2} / \mathrm{ha}\right)$ \\
\hline Larix kaempferi & $\mathrm{t}$ & 2 & 11.64 & 2.75 & 17.86 \\
\hline Pterostyrax hispida & $\mathrm{t}$ & 15 & 1.63 & - & - \\
\hline Toxicodendron trichocarpum & $\mathrm{t}$ & 2 & 1.09 & - & - \\
\hline Euonymus hamiltonianus & $\mathrm{t}$ & 2 & 0.94 & - & - \\
\hline Carpinus cordata & $\mathrm{t}$ & 5 & 0.09 & 0.25 & 0.50 \\
\hline Salix bakko & $\mathrm{t}$ & 3 & 0.08 & - & - \\
\hline Clethra barbinervis & $\mathrm{t}$ & 6 & 0.05 & - & - \\
\hline Betula ermanii & $\mathrm{t}$ & 1 & 0.04 & - & - \\
\hline Fraxinus lanuginosa & $\mathrm{t}$ & 3 & 0.03 & - & - \\
\hline Swida controversa & $\mathrm{t}$ & 1 & 0.02 & - & - \\
\hline Castanea crenata & $\mathrm{t}$ & 1 & 0.01 & - & - \\
\hline Acer diabolicum & $\mathrm{t}$ & - & - & 0.25 & 0.36 \\
\hline Acer pictum & $\mathrm{t}$ & - & - & 0.25 & 0.36 \\
\hline Hydrangea paniculata & s & 37 & 1.26 & - & - \\
\hline Aralia elata & s & 6 & 0.38 & - & - \\
\hline Callicarpa japonica & s & 36 & 0.14 & - & - \\
\hline Stephanandra incisa & s & 9 & 0.03 & - & - \\
\hline Lindera praecox & s & 1 & 0.00 & - & - \\
\hline Subtotal trees & & 41 & 15.61 & 4 & 19.09 \\
\hline Subtotal shrubs & & 89 & 1.82 & 0 & 0.00 \\
\hline Total & & 130 & 17.43 & 4 & 19.09 \\
\hline
\end{tabular}

TABLE 2: Mean values of numbers, biomass indices*, and ShannonWiener's diversity indices $H^{\prime}$ of plant species appearing in $2 \mathrm{~m} \times$ $2 \mathrm{~m}$ plots inside $(n=5)$ and outside $(n=5)$ the deer exclosure at Okutama, western Tokyo, Japan.

\begin{tabular}{lcc}
\hline & Inside & Outside \\
\hline Species number & 14.4 & 9.7 \\
Biomass index $^{*}$ & 564,710 & 39,290 \\
Diversity index $H^{\prime}$ & 2.86 & 1.77 \\
\hline
\end{tabular}

${ }^{*}$ Biomass index $=$ cover $\left(\mathrm{cm}^{2}\right) \times$ height $(\mathrm{cm})$.

The mean value of the density of deer fecal pellet groups was 3.9 group $/ 10 \mathrm{~m}^{2}$. This was lower than the result of a count made on Kinkazan Island, where deer density was as high as $50 \mathrm{deer} / \mathrm{km}^{2}$, but higher than the result obtained among deciduous broadleaved forests in the mountains of central Japan (around $1 / 10 \mathrm{~m}^{2}$ ). This suggests that the deer density in the study area is very high. In addition, we did not find any feces of other mammals, such as hare (Lepus brachyurus) or Japanese macaque (Macaca fuscata). These findings support our hypothesis that the differences in habitat inside and outside the deer exclosure can be attributed to deer grazing.

A limitation of this study is that it is restricted to one deer exclosure and therefore the conclusions must be taken with caution. However, we carefully selected locations for the plots where the topography and canopy trees were as similar

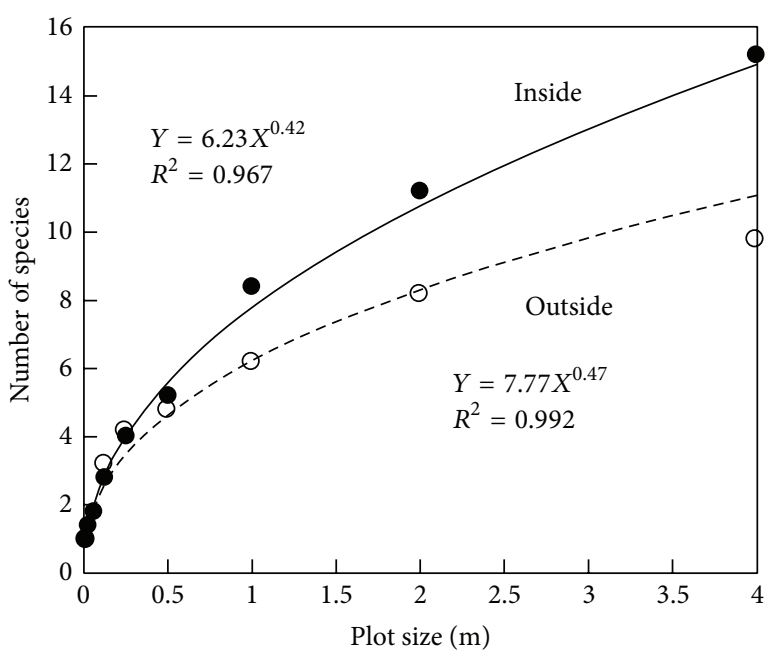

FIGURE 2: Relations of plot size and mean number of species present on each of the five $2 \mathrm{~m} \times 2 \mathrm{~m}$ plots inside and outside the deer exclosure in Okutama, western Tokyo, Japan.

as possible (see Figure 1). Despite this limitation, the data for inside and outside the exclosure showed marked differences.

The results of the undergrowth vegetation clearly showed that the values for plant species numbers, biomass, composition, and diversity were lower outside the exclosure. These differences suggest the strong direct effects of deer grazing. It is known that in many areas of central Japan, including 
TABLE 3: Mean values of biomass indices* of undergrowth plants appearing in five $2 \mathrm{~m} \times 2 \mathrm{~m}$ plots inside and outside the deer exclosure at Okutama, western Tokyo.

\begin{tabular}{|c|c|c|c|c|c|c|c|c|}
\hline & Growth from ${ }^{* *}$ & Palatability & Inside & Presentage & & Outside & Presentage & Abundant on \\
\hline Pterostyrax hispida & 1 & $\mathrm{U}$ & 400 & 0.07 & $<$ & 18400 & 46.83 & Outside \\
\hline Cynanchum caudatum & $\mathrm{t}$ & $\mathrm{U}$ & 40 & 0.01 & $<$ & 13860 & 35.28 & Outside \\
\hline Viola sieboldii & $\mathrm{r}$ & & 0 & - & $<$ & 40 & 0.10 & Outside \\
\hline Athyrium yokoscense & fe & & 0 & - & $<$ & 40 & 0.10 & Outside \\
\hline Betula ermanii & $\mathrm{t}$ & & 0 & - & $<$ & 20 & 0.05 & Outside \\
\hline Viola eizanensis & $\mathrm{r}$ & & 0 & - & $<$ & 10 & 0.03 & Outside \\
\hline Swida macrophylla & $\mathrm{t}$ & & 0 & - & $<$ & 10 & 0.03 & Outside \\
\hline Carex conica & g & & 0 & - & $<$ & 10 & 0.03 & Outside \\
\hline Festuca rubra & g & & 47500 & 8.41 & & 4200 & 10.69 & Both sides \\
\hline Carex leucochlora & g & & 1000 & 0.71 & & 2000 & 5.09 & Both sides \\
\hline Agrostis clavata & g & & 200 & 0.04 & & 420 & 1.07 & Both sides \\
\hline Viola grypoceras & $\mathrm{r}$ & & 30 & 0.01 & & 50 & 0.13 & Both sides \\
\hline Schizophragma hydrangeoides & 1 & & 20 & 0.00 & & 20 & 0.05 & Both sides \\
\hline Aralia elata & $\operatorname{sh}$ & $\mathrm{U}$ & 160000 & 28.33 & $>$ & 0 & - & Inside \\
\hline Hydrangea paniculata & 1 & & 112000 & 19.83 & $>$ & 0 & - & Inside \\
\hline Callicarpa japonica & $\operatorname{sh}$ & & 94000 & 16.65 & $>$ & 10 & + & Inside \\
\hline Symplocos sawafutagi & $\mathrm{t}$ & & 60000 & 10.62 & $>$ & 0 & - & Inside \\
\hline Clethra barbinervis & $\mathrm{t}$ & & 50420 & 8.93 & $>$ & 200 & 0.51 & Inside \\
\hline Cerasus jamasakura & $\mathrm{t}$ & & 12000 & 2.12 & $>$ & 0 & - & Inside \\
\hline Rubus crataegifolius & $\operatorname{sh}$ & & 6000 & 1.06 & $>$ & 0 & - & Inside \\
\hline Carpinus cordata & $\mathrm{t}$ & & 6000 & 1.06 & $>$ & 0 & - & Inside \\
\hline Aralia cordata & sh & & 5000 & 0.89 & $>$ & 0 & - & Inside \\
\hline Actinidia polygama & 1 & & 2440 & 0.43 & $>$ & 0 & - & Inside \\
\hline Vitis coignetiae & 1 & & 1000 & 0.18 & $>$ & 0 & - & Inside \\
\hline Celastrus orbiculatus & 1 & & 800 & 0.14 & $>$ & 0 & - & Inside \\
\hline Carex curvivicollis & g & & 800 & 0.14 & $>$ & 0 & - & Inside \\
\hline Chamaecyparis obtusa & $\mathrm{t}$ & & 800 & 0.14 & $>$ & 0 & - & Inside \\
\hline Fraxinus lanuginosa & $\mathrm{t}$ & & 400 & 0.07 & $>$ & 0 & - & Inside \\
\hline Rubus palmatus & sh & & 400 & 0.07 & $>$ & 0 & - & Inside \\
\hline Tilia japonica & $\mathrm{t}$ & & 200 & 0.04 & $>$ & 0 & - & Inside \\
\hline Clematis apiifolia & 1 & & 200 & 0.04 & $>$ & 0 & - & Inside \\
\hline Carex alopecuroides & g & & 20 & + & $>$ & 0 & - & Inside \\
\hline Quercus crispula & $\mathrm{t}$ & & 20 & + & $>$ & 0 & - & Inside \\
\hline Clinopodium multicaule & e & & 20 & + & $>$ & 0 & - & Inside \\
\hline Total & & & 564.710 & 100 & & 39.290 & 100 & \\
\hline
\end{tabular}

Biomass index ${ }^{*}=\operatorname{cover}\left(\mathrm{cm}^{2}\right) \times$ height $(\mathrm{cm})$. Growth form ${ }^{* *}$ : e: erect, fe: fern, g: graminoid, l: liane, r: rosette, sh: shrub, and t: tree. Palatability: U: unpalatable. $+:<0.1 \%$.

the area of this study, quantitative compositions of plants have been affected by deer grazing [1]. It is expected that such strong effects on plant communities would also alter habitat structure and indirectly affect insect communities [25-28, 30, 41].

The microclimate was quite different inside and outside the exclosure, suggesting that the reduction in plants caused by deer grazing increased the amount of direct sunlight, resulting in increased daytime temperatures and dryness outside the exclosure. The air temperature near the ground surface was up to $40^{\circ} \mathrm{C}$, indicating that the ground temperature must have been hotter. Humidity was always lower outside than inside, although it was $100 \%$ on many days (presumably rainy days) during the study period. These differences in microclimate would affect ground-dwelling insects. Carabid beetles were more abundant inside the exclosure, probably because of the gentle, stable microclimate inside. The habitat preferences of Japanese carabid beetles are not well known, but because forest vegetation predominates and the summer climate is humid in the Japanese archipelago, it is likely that most carabid beetles would prefer a habitat where litter is abundant and the microclimate is more humid and stable. A study on the indirect effects of sika deer on ground-dwelling insects in western Japan showed that a species of large carabid beetle, Carabus kumagai (23-36 mm in length), was more abundant in a habitat containing more Sasa nipponica, 


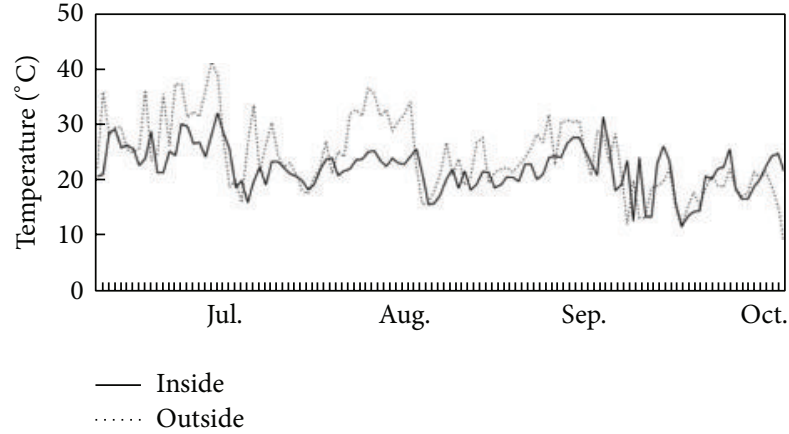

(a)

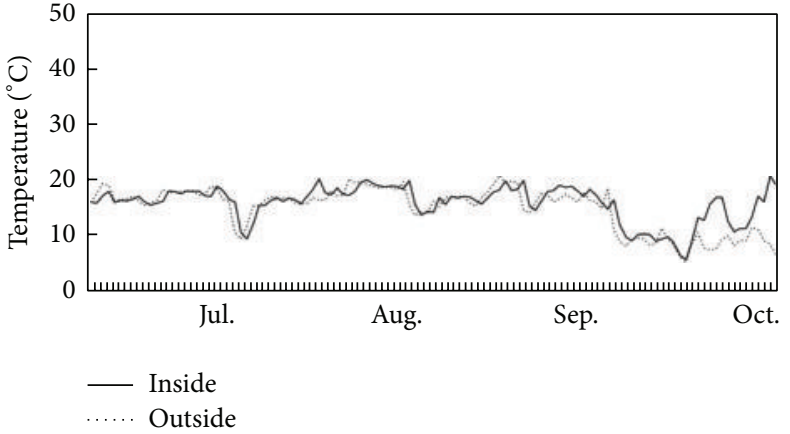

(b)

Figure 3: Daily maximum (a) and minimum (b) air temperature near the ground from late June to October, 2011, inside and outside the deer exclosure in Okutama, western Tokyo, Japan.

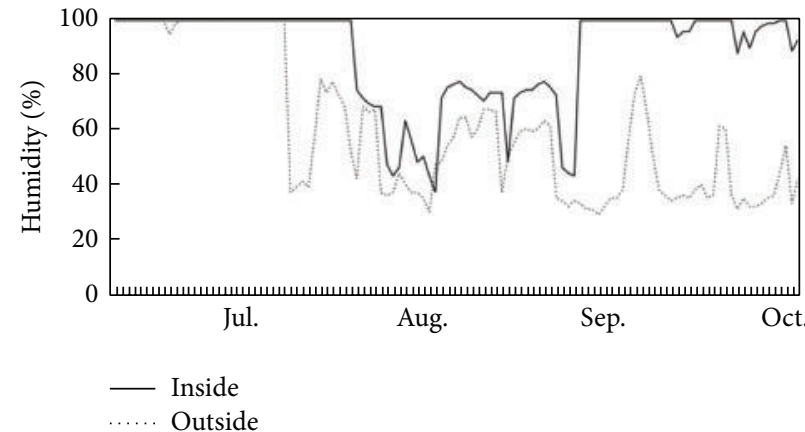

(a)

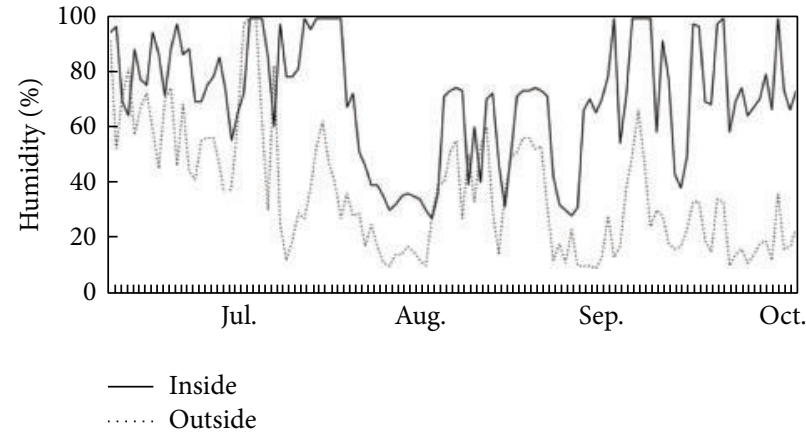

(b)

FIgURE 4: Daily maximum (a) and minimum (b) humidity near the ground from late June to October, 2011, inside and outside the deer exclosure in Okutama, western Tokyo, Japan.

TABLE 4: Numbers of insects (/100 TN; trap night) collected by pitfall traps inside and outside the deer exclosure at Okutama, western Tokyo, Japan.

\begin{tabular}{lccccc}
\hline & \multicolumn{2}{c}{ Inside } & & \multicolumn{2}{c}{ Outside } \\
& Mean & SD & & Mean & SD \\
\hline Carabid beetle (Carabinae) & 10.9 & 5.9 & $>$ & 3.8 & 2.3 \\
Carrion beetle (Silphidae) & 5.8 & 5.1 & $<$ & 8.5 & 5.8 \\
Dung beetle & 8.0 & 6.2 & $<$ & 35.5 & 5.0 \\
Camel cricket & 6.3 & 3.7 & $<$ & 12.4 & 13.8 \\
Ground beetle (Harpalinae) & 10.8 & 5.2 & & 11.1 & 6.1 \\
Rove beetle (Staphylinidae) & 2.0 & 1.6 & & 4.8 & 10.2 \\
\hline
\end{tabular}

a dwarf bamboo [31]. As many carabid beetles are flightless and prefer more stable habitats [42-44], they would provide a good reflection of differences in microenvironments. The results of our study and of a study conducted in western Japan [31] suggest that deer grazing indirectly decreases carabid beetles, in contrast to results obtained in boreal forests [2528].

It is noteworthy that more carrion beetles, dung beetles, and camel crickets were collected outside the exclosure than inside (Table 4). This indicates that some insects were favored by the presence of deer. Carrion beetles prey on carcasses, particularly of vertebrates [42]. Deer carcasses would therefore be important resources for them, as shown in Scandinavia [45]. It was not surprising that deer grazing would increase the number of dung beetles, because deer provide food resources. Similar relationships have been shown in other deer habitats in Japan, such as Kinkazan Island, Nara Park, and Miyajima Island [46]. In terms of the category of the effects of ungulates, the increase in dung beetles is not caused by an indirect effect of deer grazing but by the direct effect of providing a food resource. Effects of deer grazing are usually categorized as negative effects on herbivorous animals through plant reduction $[16,17]$ and as structural alteration of habitats $[19,20,23,47,48]$. However, increases in dung beetles and carrion beetles outside the exclosure suggest that the presence of deer is positive for these decomposers.

The higher number of camel crickets outside the exclosure is difficult to explain, as they are omnivorous and eat a wide variety of foods and are often found in dark, humid habitats. The reason for their increased presence outside the exclosure is unknown.

Soil movement on the ground was much more extensive outside the exclosure. Live plants and leaf litter help to prevent soil movement by rainfall $[34,49]$. Removal of plants and leaf litter by deer would allow raindrops to hit the soil 


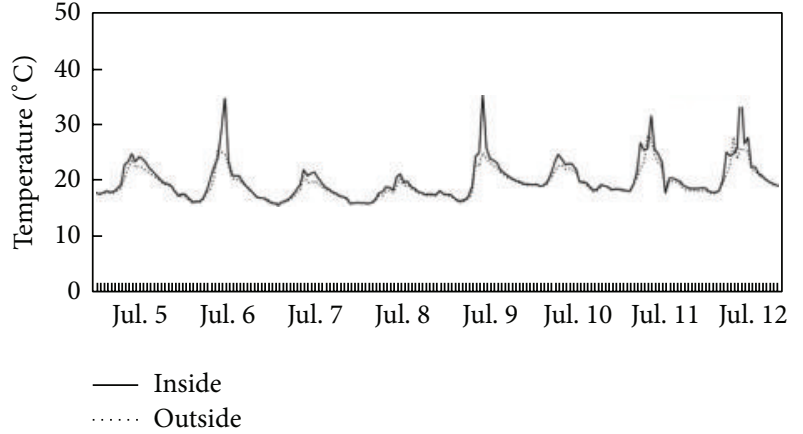

(a)

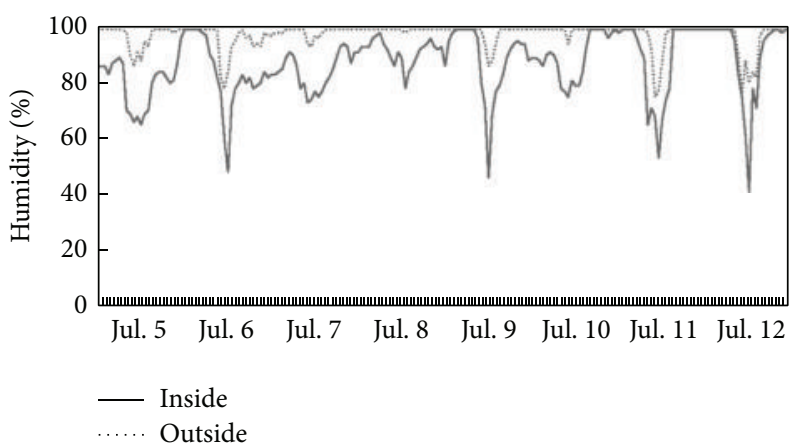

(b)

FIGURE 5: Temperature (a) and humidity (b) near the ground during representative weeks in July, 2011, inside and outside the deer exclosure in Okutama, western Tokyo, Japan.

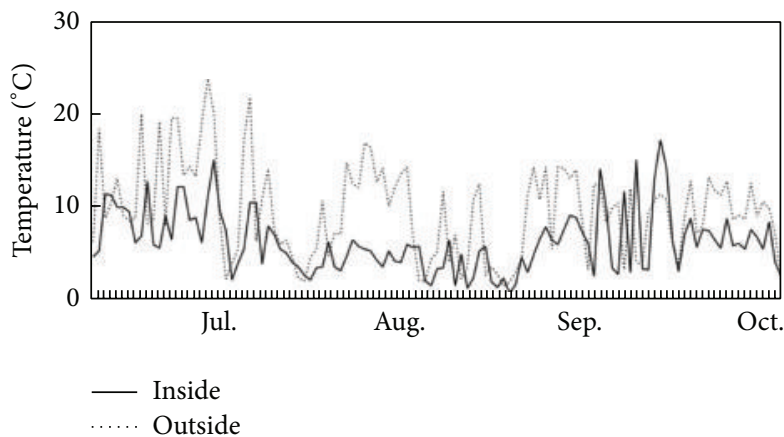

(a)

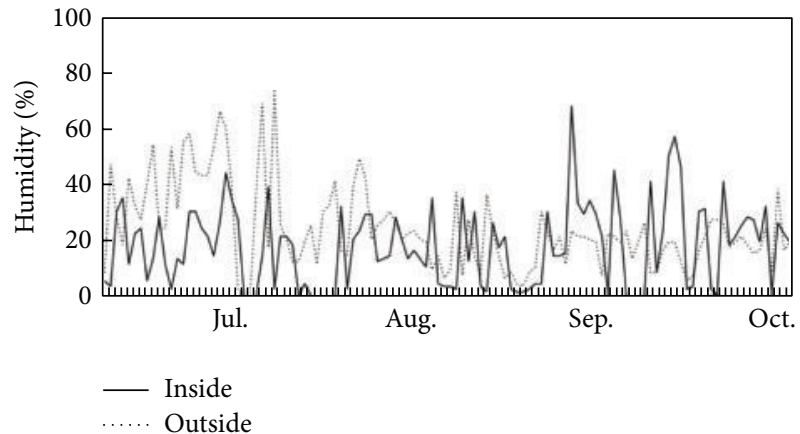

(b)

FIgURE 6: Diurnal temperature (a) and humidity (b) near the ground from late June to October, 2011 inside and outside the deer exclosure in Okutama, western Tokyo, Japan.

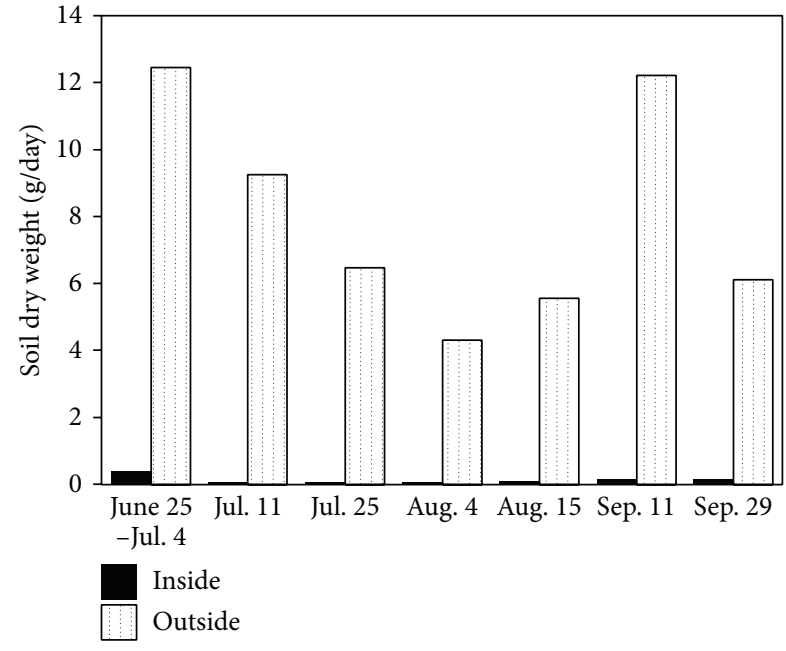

FIGURE 7: Weight of soil captured in box traps inside and outside the deer exclosure in Okutama, western Tokyo, Japan, from late June to mid-September, 2011.

directly, accelerating soil movement. This was observed at Mount Tanzawa [34] and on the Boso Peninsula [35], in eastern Japan. Sasamorpha borealis, a dwarf bamboo, once densely covered much of the study area, but its leaves have been extensively grazed by deer since approximately 2000 . This bamboo is vulnerable to grazing [50] and is rapidly decreasing in and around the study area. As the rhizomes of S. borealis are soil binding [51] and the topography of the study area is quite steep, it is quite plausible that, after decomposition of the rhizomes, soil movement would be more intensive in this area than in other locations.

\section{Conclusions}

The effects of grazing and browsing by sika deer have intensified in many parts of Japan in the last decade. Using an eight-year-old deer exclosure in western Tokyo (Japan), this study shows not only the direct effects on vegetation, but also the indirect effects on soil movements, the microclimate, and ground-dwelling insects. Plants outside the exclosure were reduced and only a few unpalatable plants survived. Because of the steep topography and high rainfall in summer, soil movement was indirectly accelerated by deer grazing outside the exclosure (Figure 8). The maximum temperature outside increased and the humidity indirectly decreased, resulting in a higher diurnal temperature and humidity range. Carabid beetles were less abundant outside, constituting an indirect 


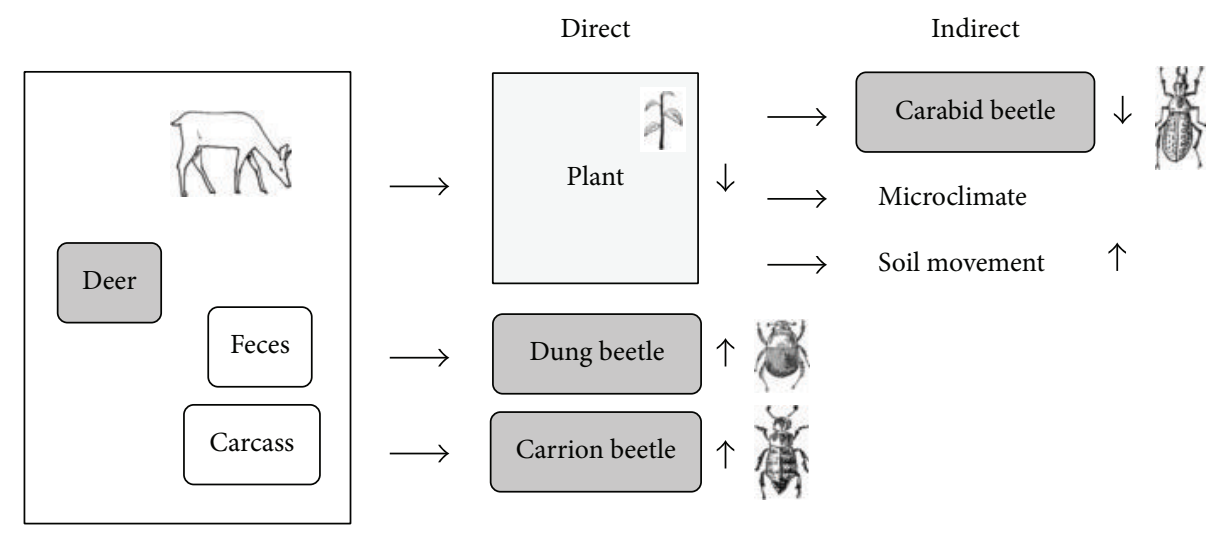

FIGURE 8: Summary of indirect effects of sika deer grazing on plants and decomposer insects and indirect effects on microenvironment, soil movements, and carabid beetles at Okutama, western Tokyo, Japan.

effect of deer grazing through abiotic environment alteration. In contrast, carrion beetles and dung beetles were more abundant outside, revealing a direct effect of deer presence (Figure 8). This study shows several patterns of the direct and indirect effects of deer grazing.

\section{Conflict of Interests}

The authors declare that there is no conflict of interests regarding the publication of this paper.

\section{Acknowledgments}

The deer exclosure was built by the Waterworks Bureau of Tokyo, which provided the opportunity to study it. This study was funded by Azabu University.

\section{References}

[1] H. Ohashi, Y. Hoshino, and K. Oono, "Long-term changes in the species composition of plant communities caused by the population growth of sika deer (Cervus nippon) in Okutama, Tokyo," Vegetation Science, vol. 24, pp. 123-151, 2007.

[2] R. Perea, M. Girardello, and A. San Miguel, "Big game or big loss? High deer densities are threatening woody plant diversity and vegetation dynamics," Biodiversity and Conservation, vol. 23, no. 5, pp. 1303-1318, 2014.

[3] G. G. Whitney, "Fifty years of change in the arboreal vegetation of ceart's content, an old-growth hemlock- white pine-northern hardwood stand," Ecology, vol. 65, no. 2, pp. 403-408, 1984.

[4] J. Pastor, B. Dewey, R. J. Naiman, P. F. McInnes, and Y. Cohen, "Moose browsing and soil fertility in the boreal forests of Isle Royale National Park," Ecology, vol. 74, no. 2, pp. 467-480, 1993.

[5] S. Takatsuki and T. Y. Ito, "Plants and plant communities on Kinkazan Island, northern Japan, in relation to sika deer herbivory," in Sika Deer: Biology and Management of Native and Introduced Populations, D. R. McCullough, K. Kaji, and S. Takatsuki, Eds., pp. 125-143, Springer, Tokyo, Japan, 2009.

[6] S. D. Côté, T. P. Rooney, J.-P. Tremblay, C. Dussault, and D. M. Waller, "Ecological impacts of deer overabundance," Annual Review of Ecology, Evolution, and Systematics, vol. 35, pp. 113147, 2004.
[7] H. Nomiya, W. Suzuki, T. Kanazashi, M. Shibata, H. Tanaka, and T. Nakashizuka, "The response of forest floor vegetation and tree regeneration to deer exclusion and disturbance in a riparian deciduous forest, central Japan," Plant Ecology, vol. 164, no. 2, pp. 263-276, 2003.

[8] S. Takatsuki and T. Gorai, "Effects of sika deer on the regeneration of a Fagus crenata forest on Kinkazan Island, northern Japan," Ecological Research, vol. 9, no. 2, pp. 115-120, 1994.

[9] A. Yamashiro and T. Yamashiro, "Seed dispersal by kerama deer (Cervus nippon keramae) on Aka Island, the Ryukyu Archipelago, Japan," Biotropica, vol. 38, no. 3, pp. 405-413, 2006.

[10] Japan Wildlife Research Center, Report of Ecology of Sika Deer for 2009, 2010 (Japanese).

[11] S. Miura and K. Tokida, "Management strategy of sika deer based on sensitivity analysis," in Sika Deer: Biology and Management of Native and Introduced Populations, D. R. McCullough, K. Kaji, and S. Takatsuki, Eds., pp. 453-472, Springer, Tokyo, Japan, 2009.

[12] Project Committee of Vegetation Science, "Impacts of Sika deer (Cervus nippon) on Japanese vegetation surveyed by questionnaire in 2009/2010," Vegetation Information, Japan, vol. 15, pp. 9-30, 2011 (Japanese).

[13] P. F. McInnes, R. J. Naiman, J. Pastor, and Y. Cohen, "Effects of moose browsing on vegetation and litter of the boreal forest, Isle Royale, Michigan, USA," Ecology, vol. 73, no. 6, pp. 2059-2075, 1992.

[14] S. G. Miller, S. P. Bratton, and J. Hadidian, "Impacts of whitetailed deer on endangered and threatened vascular plants," Natural Areas Journal, vol. 12, no. 2, pp. 67-74, 1992.

[15] S. Takatsuki, "Effects of sika deer on vegetation in Japan: a review," Biological Conservation, vol. 142, no. 9, pp. 1922-1929, 2009.

[16] W. J. McShea, "The influence of acorn crops on annual variation in rodent and bird populations," Ecology, vol. 81, no. 1, pp. 228238,2000 .

[17] L. Wheatall, T. Nuttle, and E. Yerger, "Indirect effects of pandemic deer overabundance inferred from caterpillar-host relations," Conservation Biology, vol. 27, no. 5, pp. 1107-1116, 2013.

[18] D. Baines, R. B. Sage, and M. M. Baines, "The implications of red deer grazing to ground vegetation and invertebrate communities of Scottish native pinewoods," Journal of Applied Ecology, vol. 31, no. 4, pp. 776-783, 1994. 
[19] E. W. R. Parsons, J. L. Maron, and T. E. Martin, "Elk herbivory alters small mammal assemblages in high-elevation drainages," Journal of Animal Ecology, vol. 82, no. 2, pp. 459-467, 2013.

[20] J. R. Flowerdew and S. A. Ellwood, "Impacts of woodland deer on small mammal ecology," Forestry, vol. 74, no. 3, pp. 277-287, 2001.

[21] E. Cardinal, J.-L. Martin, and S. D. Côét, "Large herbivore effects on songbirds in boreal forests: lessons from deer introduction on anticosti Island," Ecoscience, vol. 19, no. 1, pp. 38-47, 2012.

[22] D. S. Decalesta, "Effect of white-tailed deer on songbirds within managed forests in Pennsylvania," Journal of Wildlife Management, vol. 58, no. 4, pp. 711-718, 1994.

[23] W. J. McShea and J. H. Rappole, "Managing the abundance and diversity of breeding bird populations through manipulation of deer populations," Conservation Biology, vol. 14, no. 4, pp. 1161$1170,2000$.

[24] S. Allombert, S. Stockton, and J.-L. Martin, "A natural experiment on the impact of overabundant deer on forest invertebrates," Conservation Biology, vol. 19, no. 6, pp. 1917-1929, 2005.

[25] C. Melis, A. Buset, P. A. Aarrestad et al., "Impact of red deer Cervus elaphus grazing on bilberry Vaccinium myrtillus and composition of ground beetle (Coleoptera, Carabidae) assemblage," Biodiversity \& Conservation, vol. 15, no. 6, pp. 2049-2059, 2006.

[26] C. Melis, M. Sundby, R. Andersen, A. Moksnes, B. Pedersen, and E. Røskaft, "The role of moose Alces alces L. in boreal forestthe effect on ground beetles (Coleoptera, Carabidae) abundance and diversity," Biodiversity and Conservation, vol. 16, no. 5, pp. 1321-1335, 2007.

[27] O. Suominen and K. Danell, "Indirect effects of mammalian browsers on vegetation and ground-dwelling insects in an Alaskan floodplain," Ecoscience, vol. 6, no. 4, pp. 505-510, 1999.

[28] O. Suominen, J. Niemelä, P. Martikainen, P. Niemelä, and I. Kojola, "Impact of reindeer grazing on ground-dwelling Carabidae and Curculionidae assemblages in Lapland," Ecography, vol. 26, no. 4, pp. 503-513, 2003.

[29] S. M. Gardner, S. E. Hartley, A. Davies, and S. C. F. Palmer, "Carabid communities on heather moorlands in northeast Scotland: the consequences of grazing pressure for community diversity," Biological Conservation, vol. 81, no. 3, pp. 275-286, 1997.

[30] O. Suominen, K. Danell, and R. Bergström, "Moose, trees, and ground-living invertebrates: indirect interactions in Swedish pine forests," Oikos, vol. 84, no. 2, pp. 215-226, 1999.

[31] A. Ueda, T. Hino, and H. Ito, "Relationships between browsing on dwarf bamboo (Sasa nipponica) by sika deer and the structure of ground beetle (Coleoptera: Carabidae) assemblage," Journal of the Japanese Forestry Society, vol. 91, pp. 111-119, 2008 (Japanese).

[32] H. Furusawa, H. Miyanishi, and T. Hino, "Movement of soil and litter on the floor of a temperate mixed forest with an impoverished understory grazed by deer (Cervus nippon centralis Temminck)," Journal of the Japanese Forestry Society, vol. 85, no. 4, pp. 318-325, 2003.

[33] T. Inoue, T. Murakami, Y. Mitsuda, J. Miyajima, N. Mizoue, and S. Yoshida, "The relationship between bark-stripping damage to forest trees caused by sika deer (Cervus nippon) and understory vegetation," Journal of the Japanese Forestry Society, vol. 89, no. 3, pp. 208-216, 2007 (Japanese).

[34] Y. Ishikawa, "Soil erosion mechanism and the management in the forest of poor undergrowth at Mt. Tanzawa, Eastern Japan," Forest Science, vol. 53, pp. 48-52, 2008.
[35] Y. Yanagi, M. Takada, and T. Miyashita, "Changes in the physical properties of forest soils in the Boso Peninsula due to sika deer revealed by surveys and a field experiment," Japanese Journal of Conservation Ecology, vol. 13, no. 1, pp. 65-74, 2008 (Japanese).

[36] S. Shimane and K. Nakabayashi, "Properties of humus on the brown forest soil developed under spruce and Tsuga diversifolia Mast. Forest in Okutama district," Bulletin of Faculty of Agriculture, Meiji University, vol. 78, pp. 93-98, 1988 (Japanese).

[37] Tokyo Environment Bureau, Project for Deer Management in Tokyo-Looking for Prosperous Forest Where People and Deer Can Coexist, Tokyo Prefecture, 2005, (Japanese).

[38] S. Takatsuki and M. Sato, "Biomass index for the steppe plants of northern Mongolia," Mammal Study, vol. 38, no. 2, pp. 131-133, 2013.

[39] C. H. Gimingham, "The use of life form and growth form in the analysis of community structure, as illustrated by a comparison of two dune communities," Journal of Ecology, vol. 39, no. 2, pp. 396-406, 1951.

[40] M. Ikuno, "A method for ground beetles by pit-fall traps," Insects and Nature, vol. 37, pp. 8-11, 2002 (Japanese).

[41] A. J. A. Stewart, "The impact of deer on lowland woodland invertebrates: a review of the evidence and priorities for future research," Forestry, vol. 74, no. 3, pp. 259-270, 2001.

[42] H. Ikeda, "The ecology of the flightless carrion beetles," Japanese Journal of Entomology (New Series), vol. 14, pp. 133-138, 2011 (Japanese).

[43] S. Suzuki, "Why Nicrophorus beetles are burial beetles?" in Natural History of Beetle in Forest and Riparian Habitat, pp. 85101, Tokai University Press, 2006, (Japanese).

[44] D. L. Wagner and J. K. Liebherr, "Flightlessness in insects," Trends in Ecology and Evolution, vol. 7, no. 7, pp. 216-220, 1992.

[45] C. Melis, I. Teurlings, J. D. C. Linnell, R. Andersen, and A. Bordoni, "Influence of a deer carcass on Coleopteran diversity in a Scandinavian boreal forest: a preliminary study," European Journal of Wildlife Research, vol. 50, no. 3, pp. 146-149, 2004.

[46] K. Tsukamoto, M. Inagaki, M. Kawahara, and M. Mori, Dung Beetles, Tombo Press, 2007 (Japanese).

[47] T. P. Rooney, "Deer impacts on forest ecosystems: a North American perspective," Forestry, vol. 74, no. 3, pp. 201-208, 2001.

[48] T. P. Rooney and D. M. Waller, "Direct and indirect effects of white-tailed deer in forest ecosystems," Forest Ecology and Management, vol. 181, no. 1-2, pp. 165-176, 2003.

[49] J. Aoki, Soil Zoology, Revised Version, Hokuryukan, 2010, (Japanese).

[50] W. Agata, F. Kubota, and E. Kamata, "Ecological characteristics and dry matter production of some native grasses in Japan, II. Effect of time and frequency of cutting on dry matter production in Sasa nipponica community," Journal of Japanese Grassland Science, vol. 25, pp. 110-116, 1979.

[51] T. Koizumi, T. Yabe, and S. Inoue, "The effects of sika deer, Cervus nippon, grazing on the density and height of a dwarf bamboo, Sasamorpha borealis, in southwestern Japan," Kyushu Journal of Forest Research, vol. 59, pp. 90-93, 2006 (Japanese). 

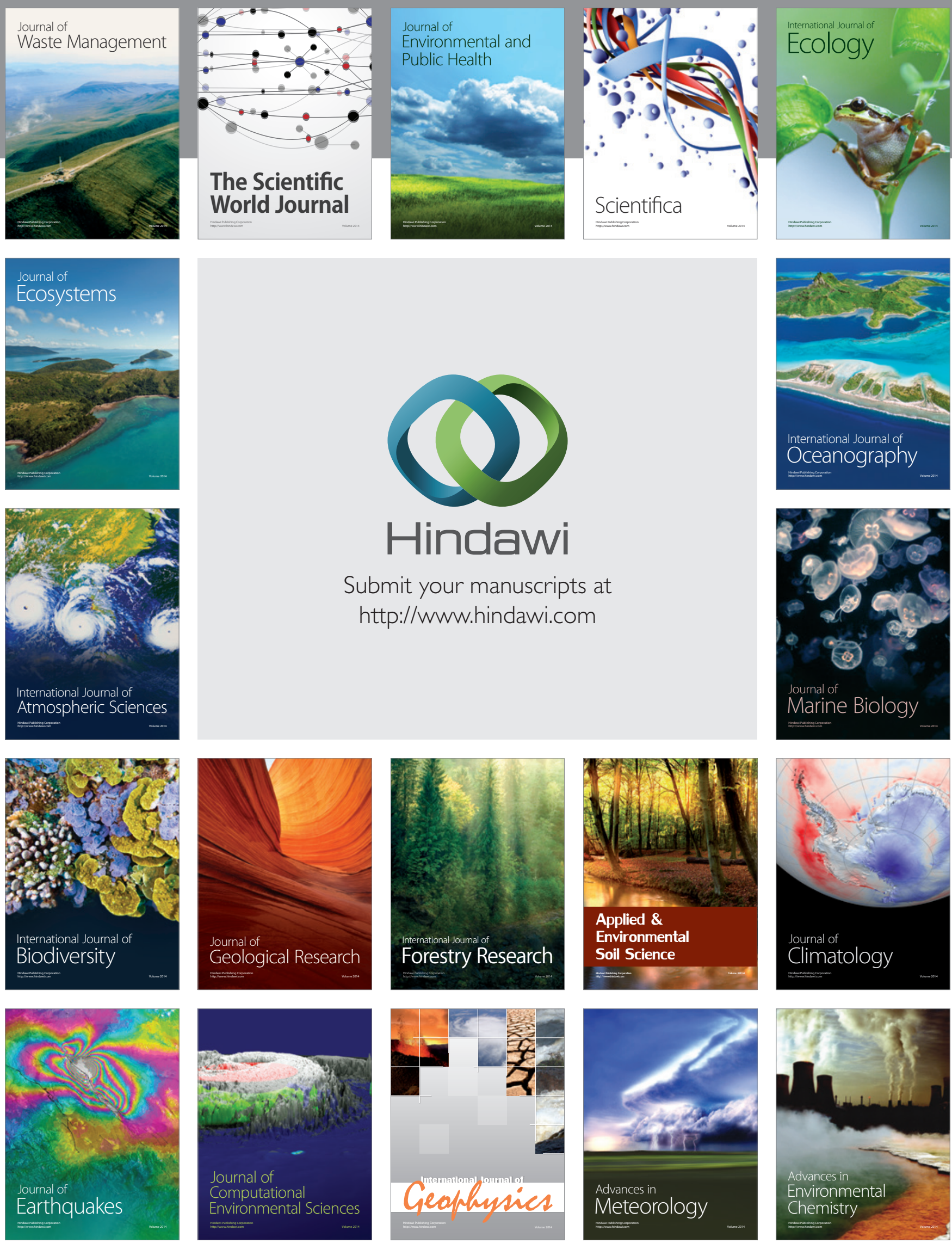